Bull. Fac .Agric., Cairo Univ. 67:285- 294 (2016).

\title{
PERFORMANCE OF YIELD AND ITS COMPONENTS OF FOURTEEN HULL-LESS BARLEY GENOTYPES GROWN IN FIVE LOCATIONS IN EGYPT
}

\author{
(Received:12.12.2016)
}

\author{
By \\ M.S. Abdel-Raouf , A.A. Kandil , A.A. El-Sayed* and A.M. Attya* \\ Agronomy Department, Faculty of Agriculture, Cairo University, Giza, Egypt. \\ * Barley Research Department, Field Crops Research Institute, \\ Agricultural Research Center, Giza, Egypt.
}

\begin{abstract}
Barley performance varies among genotypes and/or due to the different response of a genotype to the prevailing climatic factors where it is grown. The aim of the present investigation was to study the performance of some promising lines and new varieties as well as some cultivars of hull-less barley under the conditions of five locations of Egypt, to identify which one could be grown and produce high grain yield all over locations or in a specific location. This investigation was carried out at five locations (Nubaria, Sakha, Gimmeza, Quntra Sharq and Giza) in two seasons (2013/2014 and 2014/2015) using a randomized complete block design with three replications and 14 genotypes, i.e. 9 promising lines, three cultivated varieties Giza 129, Giza 130 and Giza 131 and the two new varieties Giza 135 and Giza 136. Results indicated a negative and significant correlation between either days to flowering or days to maturity and grain yield and its components in both seasons and combined across seasons. The results showed that L2 and L3 are promising lines, Giza 135 and Giza 136 new varieties produced high yield and its components. From these results it could be concluded that the most suitable genotypes for Nubaria location were L2, L3, L4 and Giza 136 while the most suitable ones for Sakha and Gimmeza locations were L2, L3 and Giza 136. However, Giza 136, Giza 135 and L3 were the most suitable genotypes for Quntra Sharq location. Meanwhile, L2, L3, L7 and Giza 136 genotypes were superior at Giza location. This means that L3 genotype and Giza 136 cultivar had stable productivity under the conditions of these locations. Also L3 genotype was a promising line to be released as a good variety in general and under high productive environments in particular. However, Giza 136 was stable and also adapted to less productive environments.
\end{abstract}

Keywords: Hordem vulgare L., Grain Yield, Simple correlation, linear regression, Coefficient of determination.

\section{INTRODUCTION}

Barley is an important cereal crop in some areas in Egypt such as North -West Coast, North Saini and the New valley. The Bedwans used its grain as feed for their sheep as well as food. Barley is the most suitable crop to be grown in such areas under rainfed conditions because of its short growing season as well as its relative tolerance to drought. However, hull-less barley took attention in the last few years, as it could be used as human food and to manufacture some healthy foods.

Barley performance may vary among genotypes due to the different responses of a genotype to the prevailing climatic factors where it is grown. High grain filling rate was attributed to high kernel weight, but not to grain filling period or grain yield (Dofing, 1995). He also found a marked variation among 17 barley genotypes in grains/spike, kernel weight, spike $/ \mathrm{m}^{2}$ and grain yield. Also, differences among wheat varieties were recorded under rainfed and irrigation conditions (Okuyama et $a l ., 2004)$. They added that grain yield was positively correlated with spikes $/ \mathrm{m}^{2}$, grains/spike and top dry weight under irrigated conditions, and also with grain yield. Similar results were found by Ataei (2006) when 20 lines of six- rowed barley were used.

Barley showed a reduction trend in yield when grown in warm locations in India (Kalra $e t$ al., 2008). They reported that the maximum reduction was observed in Haryana where grain yield decreased by $5.01 \mathrm{q} / \mathrm{ha}$ for each seasonal 
temperature increase by one degree $\left(\mathrm{C}^{\mathrm{o}}\right)$, while this reduction was $1.81 \mathrm{q} / \mathrm{ha}$ in Punjab.

Tsenov (2009) planted ten early and late winter wheat varieties and lines in Bulgaria. A ten days difference in days to heading between the two groups was reported. However, days from heading to physiological maturity differed by 1.4 days only, which may be due to the fact that days to heading of winter wheat varieties was affected by air temperature more than the days from heading to physiological maturity. However, in Jordan, Al-Tabbal and Al- Fraihat (2012), using 71 barley genotypes in two seasons, found that the greater number of spike/ $\mathrm{m}^{2}$ and the number of grains/spike are major components for high grain yield.

Air and soil temperatures during the early or late growing season showed different effects on grain yield of different wheat and barley genotypes (Hossain et al., 2012). They concluded that it is important to grow the suitable variety tolerant to stress conditions during the sensitive growth stage in a specific location.

Negative effect on yield and quality of barley was noted due to high temperature during flowering. However, low temperature seems to have a positive effect (Reinhardt et al., 2013).

In the Mediterranean region, Yau and Ryan (2013) grew barley, lentil and common vetch in Alepo, Syria and found a significant correlation between grain yield and precipitation during March-May for barley. Average temperature during Jan.-Feb., rainfall during March-May and average temperature during May were the most important weather parameters,in ascending order, affecting grain yield of barley.

Differences in phenological and morphological traits were found among barley genotypes grown in Iran (Abad et al., 2013). Similar results were found in Chad (Nwaosu and Onuche, 2014) who classified the tested barley genotypes into three groups according to maturity data. Also, they reported that the late and moderate mature varieties produced greater yield than the early mature ones. For that, Talukder et al. (2014), in Australia, reported that the longer post-heading duration in wheat had better tolerance to heat stress than the short ones. However, they concluded that a single day of heat stress near flowering and early grain set can reduce grain yield.
In China, based on experiment results at 120 research stations from $1981-2009$, Tao et al. (2014) found that climatic change caused marked impacts on wheat growth and productivity in the major wheat producing regions in China. They concluded that agronomic management and cultivars turnover still play an important role in adaptation to climatic change. For that, Mondal et al. (2016) suggested that earliness could be a key criterion in breeding for heat stress tolerance in South Asia. Short duration wheat varieties are preferred by farmers due to their low input requirements and use in rotation with other crops. However, they found a negative genetic correlation between grain yield and days to heading. In Turkey, Montazeaud et al. (2016) stated that the stay-green phenotype proved to be an important trait to improve yield in low rainfall winter wheat growing areas. They pointed out a four stage-green parameters, i.e. onset of senescence, maximum greenness attained, rate of senescence and residual greenness at maturity should be taken together in consideration.

The current investigation aimed to study the performance of some promising lines and new varieties as well as some cultivars of hullless barley under the conditions of five locations of Egypt, to identify which one could be grown and produce high grain yield all over locations or in a specific location.

\section{MATERIALS AND METHODS}

Ten field experiments were carried out at five locations (Nubaria, Sakha, Gimmeza, Quntra Sharq and Giza) in Egypt in two successive seasons (2013/2014 and 2014/2015) in three replications with a RCBD randomized complete block design by using 14 genotypes to study the performance and simple correlation, regression of determination and linear equation between phenological traits and yield and its components.

\subsection{Plant materials}

The experimental materials for the present study consisted of 14 barley genotypes. These genotypes were 9 promising lines (L1, L2, L3, L4, L5, L6, L7, L8 and L9), three cultivated varieties (Giza 129, Giza 130, and Giza 131) and two new varieties (Giza 135 and Giza 136). Name, pedigree and source of these genotypes 
Table(1): Name, pedigree and seed source of 14 - 6-rowed hull-less barley genotypes.

\begin{tabular}{llc}
\hline Ent. & Name or Cross / Pedigree & Seed Source* \\
\hline L1 & GIZA 129// HIPROLY & EGYPT \\
L2 & GIZA 130/10/ APETO/5/GLORIA-BAR/4/SOTOL// 2762/BC-B/3/11012.2/TERN-B/6/H272 & EGYPT \\
& /7/SEN/8/MJA/9/PETUNIA 1/10/CABUYA & \\
L3 & GIZA 2000/11/ APETO/5/GLORIA-BAR/4/SOTOL// 2762/BC-B/3/11012.2/TERN-B/6/H272 & EGYPT \\
& /7/SEN/8/MJA/9/PETUNIA 1/10/CABUYA & \\
L4 & GIZA 200/5/LIGNEE640/PI382798//DC-B/3/CABUYA/4/PETUNIA 1 $1 /$ EGYPT \\
L5 & CARDO/LINO//CHINIA/3/ALISO/4/CI3909-2/5/FALCON-BAR/6/HIGO & EGYPT \\
L6 & GIZA 117/6/ GLORIA-BAR/COPAL//PM5/3/BEN/4/ SEN/5/PETUNIA 1 & EGYPT \\
L7 & GIZA 126/3/CABUYA/MJA//PETUNIA 1 & EGYPT \\
L8 & GIZA 126/6/ P.STO/3/LBIRAN/UNA80//LIGNEE640/4/BLLU/5/PETUNIA 1 & EGYPT \\
L9 & GIZA 13//PETUNIA 1/CHINIA & EGYPT \\
G129 & Deir Alla106/Cel//As 46/Aths*2 & EGYPT \\
G130 & CC229//Bco.Mr./DZ02391/3/Deir Alla106 & EGYPT \\
G131 & CM67-B/CENTENO//CAM-B/3/ROW906.73/4/GLORIA-BAR/COME-B/5/FALCON- & EGYPT \\
& BAR/6/LIN & \\
G135 & ZARZA/BERMEJO/4/DS4931//GLORIA-BAR/COPAL/3/SEN/5/ANYAROSA & EGYPT \\
G136 & PLAISANT/7/CLN-B/4/S.P-B/LIGNEE640/3/S.P-B//GLORIA-BAR/COME-B/5/FALCON- & EGYPT \\
& BAR/6/LINO &
\end{tabular}

*The Egyptian/ European Project on Sustainable Barley Production in Rainfed Areas in Egypt.

are given in Table (1).

\subsection{Description of the experimental sites}

The description of the experimental sites including soil analysis, location and meteorological data is presented in Tables ( 2,3 and 4 , respectively) .

\subsection{Traits recorded}

2.3. 1. Days to heading calculated according to the date of head appearance of $50 \%$ of plant plots.

2.3.2. Days to maturity the data when peduncle of $>50 \%$ of plants become yellow.

2.3.3. Grain filling period estimated in days as the difference between days to maturity and days to heading.

2.3.4. Number of spikes $/ \mathrm{m}^{2}$ estimated at harvest from one meter square area.

2.3.5. Number of grains/spike as an average of 10 spikes.

2.3.6. Grain weight/spike as an average of 10 spikes.

2.3.7. 1000-kernels weight estimated from a random sample from each plot.

2.3.8. Grain yield ton/ha estimated on whole plot basis.

\subsection{Statistical analysis}

Analysis of variance (ANOVA) was conducted for each location. Homogeneity test of experimental error variances were performed according to procedures reported by Gomez and Gomez (1984). Then, combined analyses of variance across locations and seasons were performed.

\section{RESULT AND DISCUSSION}

\subsection{Effect of seasons}

Mean square of the studied traits due variation sources of the combined analysis are presented in Table (6). Results show significant and high significant effect for the seasons on the studied traits, except number of spikes $/ \mathrm{m}^{2}$ and grain filling period. This means there was a marked difference between seasons with regard to some climatic factors prevailed during the growing season of hull-less barley (Table 4). Air temperature during growing seasons in general ,and particularly, during anthesis seems to be the most climatic factor affecting growth and yield of barley (Kalra et al., 2008 ; Podlesny and Podlesna, 2012 and Tao et al., 2014). However, Yau and Ryan (2013) reported that the average temperature during Jan.-Feb., rainfall during

Table (2): Mechanical and chemical analysis of locations soil* .

\begin{tabular}{|l|c|c|c|l|l|l|l|l|l|l|}
\hline \multirow{2}{*}{ Location } & \multicolumn{3}{|c|}{ Available(ppm) } & pH & $\begin{array}{l}\text { Ec } \\
\mathbf{d c} / \mathbf{m}\end{array}$ & $\begin{array}{l}\text { CaCo } \\
\mathbf{3 \%}\end{array}$ & $\begin{array}{l}\text { Clay } \\
\mathbf{\%}\end{array}$ & $\begin{array}{l}\text { Silt } \\
\mathbf{\%}\end{array}$ & $\begin{array}{l}\text { Sand } \\
\mathbf{\%}\end{array}$ & Soil texture* \\
\cline { 2 - 10 } Nubaria & 54.2 & 2.6 & 290 & 8.2 & 5.4 & 22.8 & 11.5 & 24.6 & 63.9 & Sandy Loam \\
\hline Sakha & 66.8 & 8.0 & 430 & 8.1 & 3.0 & 1.32 & 54.4 & 9.20 & 36.4 & Clay Loam \\
\hline Gimmeza & 53.2 & 18.6 & 490 & 7.7 & 2.01 & 3.86 & 39.6 & 41.8 & 18.6 & Clay \\
\hline Q. sharq & 45.0 & 6.6 & 144 & 7.8 & 1.09 & 1.23 & 7.5 & 2.1 & 91.3 & Sandy \\
\hline Giza & 65.0 & 8.6 & 335 & 7.8 & 1.15 & 1.43 & 50.4 & 38.3 & 11.3 & Loam \\
\hline
\end{tabular}

* These analysis were done by soil and water Research Institute, ARC, Egypt. 
Table (3): Location and elevation data for the experimental sites.

\begin{tabular}{|l|l|l|l|}
\hline Site & latitude & longitude & Altitude (asl*) \\
\hline Nubaria & $3112 \mathrm{~N}$ & $2957 \mathrm{E}$ & $7 \mathrm{~m}$ \\
\hline Sakha & $3107 \mathrm{~N}$ & $3057 \mathrm{E}$ & $10 \mathrm{~m}$ \\
\hline Gimmeza & $3048 \mathrm{~N}$ & $3107 \mathrm{E}$ & $9 \mathrm{~m}$ \\
\hline $\begin{array}{l}\text { Quntra } \\
\text { Sharq }\end{array}$ & $3117 \mathrm{~N}$ & $3227 \mathrm{E}$ & $14 \mathrm{~m}$ \\
\hline Giza & $3002 \mathrm{~N}$ & $3113 \mathrm{E}$ & $22 \mathrm{~m}$ \\
\hline
\end{tabular}

*asl= above sea leavel

March-May and average temperature the during May were the most important weather parameters in ascending order affecting grain yield of barley.

\subsection{Effect of locations}

Table (6) also showed significant and high significant effect due to locations on all the studied traits. Results in Table (7) cleared that Sakha location produced the highest grain yield ( $t /$ ha) followed by Gimmeza location with small difference between them in both and across seasons. This was attributed to the high value of grain weight/spike, the number of grain/spike and the number of spikes $/ \mathrm{m}^{2}$ in combined data (Table 7). On the other hand, Quntra Sharq produced the least grain yield $\mathrm{t} / \mathrm{ha}$; this was attributed to the least values of the aforementioned three yield components.

However, Quntra Sharq ranked second with regard to 1000-kernal weight in the combined data (Table 7). The superiority of Sakha and Gimmeza locations in grain yield compared to other locations may be due to the favorable climatic factors such as temperature and the highest rainfall among locations which may avoid drought or heat stress during the growing season. On the other side, the least grain yield of Quntra Sharq may be due to its less fertile soil, rare rainfall and its sandy soil texture (Table 2). Such characteristic of Quntra Sharq location may have induced some kind of stress during the growing season which negatively affected all of yield components except 1000-kernal weight (Table 7). The variation in grain yield among different locations may be due to variation in physical and chemical characteristic of location soils and/or variation in weather parameters such as rainfall rate in rainfed agriculture and air temperature prevailing during the growing seasons (Dofing, 1995; Okuyama et al., 2004; Al-Tabbal and Al-Fraihat, 2012; Abad et al., 2013; Talukder et al., 2014; Lodhi et al., 2015 and Mondal et al., 2016).

3.3.Effect of genotypes
Results in Table (6) cleared that the genotypes differed significantly and highly significantly in all the studied traits, except grain filling period. Grain yield ranged from 3.96 t/ha (L6) to 6.56 t/ha (L3) based on the combined data. According to L.S.D 0.05 value of combined analysis of tested genotypes could be classified into four groups with regard to their grain yield potentiality: 1- High yield potential genotypes of 5.79 - 6.56 t/ha (L2. L3, Giza 136 and Giza 135). 2- Relative high yield potential genotypes of 5.06 - 5.34 t/ha (Giza 129, Giza 131 and L8). 3- Moderate yield potential genotypes of 4.38 4.84 t/ha (L1, L4, L7, L9 and Giza 130). 4- Low yield potential genotypes of $3.96-4.10 \mathrm{t} / \mathrm{ha}$ (L5 and L6).

The highest grain yield of the first group was accompanied with high values of yield components, i.e. spikes $/ \mathrm{m}^{2}$, grains/spike, 1000kerneal weight and grain weight/spike (Table 8). On the other side, the low grain yield of the fourth group was also accompanied by the low values of the yield components. The superiority of L2, L3, Giza 135 and Giza 136 may be due to their short vegetative growth stage (days to heading) which ranged from 82.6 to 85.1 days (Table 8) compared with the grand mean (89.5 days) or with low yield potential genotype L6 (99.0 day) and L7 (100.2 day). The short vegetative growth stage of the high yield potential genotypes make them flower early before air temperature rise during the grain filling period (April and May) as shown in Table (4).

Table (9) shows a negative and significant correlation between either days to flowering or days from sowing to maturity and grain yield and its components in across seasons. However, the coefficient of determination $\left(\mathrm{R}^{2}\right)$ of grain yield and its components was high due to days from sowing to maturity and moderate due to days from sowing to heading, while it was low due to days from heading to maturity (Table 9). This means that the simple linear regression equation is fit to explain the variation in yield and its components due to days from sowing to maturity as independent factor (Table 9). The variation in grain yield and its components among the tested genotypes may be due to the different genetic background as well as different response to different environments. Similar results were also found by (Dofing, 1995; Okuyama et al., 2004; Al-Tabbal and AlFraihat, 2012; Abad et al., 2013; Talukder et al., 
Table (4): Meteorological data of the experimental sites.

\begin{tabular}{|c|c|c|c|c|c|c|c|c|c|c|}
\hline & \multicolumn{4}{|c|}{$2013 / 2014$} & \multirow[b]{2}{*}{ Giza } & \multirow[b]{2}{*}{ Nub. } & \multicolumn{4}{|c|}{$2014 / 2015$} \\
\hline & Nub. & Sak. & Gim. & Q.sh. & & & Sak. & Gim. & Q.sh. & Giza \\
\hline \multicolumn{11}{|c|}{ December } \\
\hline Average temp. $\left(\mathrm{c}^{0}\right)$ & 14.9 & 15.2 & 14.2 & 15.3 & 15.2 & 16.4 & 15.4 & 15.9 & 17.1 & 19.0 \\
\hline Average rainfall $(\mathrm{mm})$ & 36.6 & 61.6 & 54.3 & 19.0 & 8.0 & 43.0 & 77.3 & 50.7 & 20.6 & 6.0 \\
\hline Aver. Relative humidity (\%) & 74.0 & 96.0 & 92.0 & 80.0 & 68.0 & 69.0 & 90.0 & 88.0 & 73.0 & 56.0 \\
\hline Aver. Wind speed (m/sec) & 2.2 & 3.2 & 2.9 & 3.1 & 1.0 & 1.7 & 2.9 & 2.7 & 2.6 & 1.5 \\
\hline Aver. Sunshine duration (hr) & 10.0 & 10.1 & 10.0 & 10.0 & 10.1 & 10.0 & 10.1 & 10.0 & 10.0 & 10.2 \\
\hline \multicolumn{11}{|c|}{ January } \\
\hline Average temp. $\left(\mathrm{c}^{0}\right)$ & 14.6 & 14.6 & 13.9 & 16.1 & 15.5 & 13.6 & 14.2 & 13.7 & 14.2 & 15.8 \\
\hline Average rainfall $(\mathrm{mm})$ & 12.0 & 13.3 & 11.7 & 8.6 & 3.0 & 12.6 & 22.0 & 18.9 & 9.1 & $4 . .0$ \\
\hline Aver. Relative humidity (\%) & 80.0 & 94.0 & 94.0 & 89.0 & 66.6 & 66.7 & 90.0 & 88.0 & 71.3 & 54.3 \\
\hline Aver. Wind speed (m/sec) & 1.4 & 3.7 & 3.5 & 2.5 & 1.5 & 2.9 & 3.9 & 3.2 & 3.5 & 2.1 \\
\hline Aver. Sunshine duration (hr) & 10.2 & 10.3 & 10.2 & 10.2 & 10.3 & 10.2 & 10.2 & 10.2 & 10.2 & 10.5 \\
\hline \multicolumn{11}{|c|}{ February } \\
\hline Average temp. $\left(\mathrm{c}^{0}\right)$ & 15.6 & 16.2 & 16.8 & 16.5 & 16.9 & 14.1 & 15.8 & 13.4 & 14.4 & 16.3 \\
\hline Average rainfall $(\mathrm{mm})$ & 6.1 & 18.2 & 16.5 & 7.6 & 1.9 & 22.7 & 17.9 & 14.6 & 8.1 & 2.0 \\
\hline Aver. Relative humidity (\%) & 75.0 & 61.0 & 76.0 & 82.0 & 60.9 & 67.0 & 63.0 & 59.0 & 71.3 & 53.2 \\
\hline Aver. Wind speed (m/sec) & 2.1 & 2.8 & 3.7 & 3.1 & 2.1 & 3.1 & 3.1 & 3.7 & 3.6 & 2.2 \\
\hline Aver. Sunshine duration (hr) & 11.1 & 11.2 & 11.3 & 11.0 & 11.0 & 11.0 & 11.1 & 11.3 & 11.0 & 11.0 \\
\hline \multicolumn{11}{|c|}{ March } \\
\hline Average temp. $\left(\mathrm{c}^{0}\right)$ & 17.0 & 17.4 & 16.3 & 17.6 & 19.1 & 16.9 & 17.6 & 16.6 & 17.6 & 21.0 \\
\hline Average rainfall $(\mathrm{mm})$ & 2.9 & 12.6 & 24.6 & 6.3 & 10.0 & 2.1 & 10.2 & 3.6 & 2.4 & 4.0 \\
\hline Aver. Relative humidity (\%) & 70.0 & 84.0 & 86.0 & 83.0 & 60.4 & 66.3 & 88.0 & 83.0 & 73.3 & 51.6 \\
\hline Aver. Wind speed (m/sec) & 2.5 & 3.1 & 2.7 & 3.8 & 2.9 & 2.7 & 3.4 & 3.3 & 3.7 & 2.3 \\
\hline Aver. Sunshine duration (hr) & 11.8 & 11.8 & 11.7 & 11.8 & 11.8 & 11.8 & 11.8 & 11.8 & 11.8 & 11.5 \\
\hline \multicolumn{11}{|c|}{ April } \\
\hline Average temp. $\left(\mathrm{c}^{0}\right)$ & 19.8 & 20.4 & 18.6 & 20.3 & 23.5 & 18.2 & 19.6 & 18.0 & 18.5 & 23.6 \\
\hline Average rainfall $(\mathrm{mm})$ & 0.0 & 5.0 & 10.2 & 3.5 & 0.0 & 3.7 & 6.3 & 10.0 & 2.9 & 0.0 \\
\hline Aver. Relative humidity (\%) & 70.0 & 83.0 & 82.0 & 74.0 & 59.4 & 64.3 & 82.0 & 77.0 & 72.0 & 43.1 \\
\hline Aver. Wind speed (m/sec) & 2.2 & 2.9 & 2.9 & 3.6 & 2.9 & 3.1 & 3.3 & 3.1 & 4.3 & 2.7 \\
\hline Aver. Sunshine duration (hr) & 12.8 & 12.8 & 12.9 & 12.8 & 12.8 & 12.8 & 12.8 & 12.9 & 12.8 & 12.4 \\
\hline \multicolumn{11}{|c|}{ May } \\
\hline Average temp. $\left(\mathrm{c}^{0}\right)$ & 23.0 & 23.5 & 24.1 & 23.3 & 27.0 & 22.3 & 23.8 & 24.3 & 22.4 & 28.7 \\
\hline Average rainfall(mm) & 0.0 & 0.0 & 0.0 & 5.0 & 0.0 & 0.0 & 0.0 & 0.0 & 2.0 & 0.0 \\
\hline Aver. Relative humidity (\%) & 63.0 & 81.0 & 77.0 & 65.0 & 52.8 & 63.7 & 83.0 & 80.0 & 69.0 & 41.6 \\
\hline Aver. Wind speed (m/sec) & 2.7 & 2.8 & 2.7 & 3.4 & 2.7 & 2.8 & 2.9 & 2.8 & 3.9 & 2.5 \\
\hline Aver. Sunshine duration (hr) & 13.4 & 13.4 & 13.5 & 13.6 & 13.5 & 13.6 & 13.4 & 13.5 & 13.6 & 13.5 \\
\hline
\end{tabular}

2014; Lodhi et al., 2015 and Mondal et al., 2016).

\subsection{Effect of interactions}

Table (6) indicates that most studied traits were significantly affected by all the interactions. However, the most important interaction in this study is the location $\mathrm{x}$ genotype interaction. According to this interaction, it might identify which genotype is suitable to grow in a specific location. From Table (10) it could be concluded that L3 genotype produced high grain yield all over all locations. It ranked the $1^{\text {st }}$ in three locations (Sakha, Gimmeza and Giza) out of the five ones. It ranked the $2^{\text {nd }}$ in Nubaria, and $3^{\text {rd }}$ in Quntra Sharq (Table 10). Without significant difference between the 4 locations, except Quntra Sharq.
Data in the Table (10) show that L4 genotype ranked $1^{\text {st }}$ at Nubaria location with valuable difference from other locations. However, Giza 136 ranked $1^{s t}$ at Quntra Sharq location. From the results in Table (10) it could be concluded that Giza 136 variety is suitable to grow in Quntra Sharq location because it produced the highest grain yield significantly over the other tested 13 genotypes. Also, the reduction in its grain yield than the highest productive location (Sakha) and Quntra Sharq was $26.8 \%$ compared to a reduction rate of $40.4 \%$ for L3 and $67.8 \%$ for L4. This means that Giza 136 is suitable to grow in all locations in general and in Quntra Sharq in particular.

Data in Table (10) also indicated that L4 genotype is suitable to grow at Nubaria location 
Table (5): Cultural practices carried out at different locations in the two seasons.

\begin{tabular}{|c|c|c|c|c|c|}
\hline & Nubaria & Sakha & Gimmeza & Quntra sharq & Giza \\
\hline \multicolumn{6}{|c|}{$2013 / 2014$} \\
\hline Seeding date & Dec., 1 st week & Dec., 1 st week & Dec., 1 st week & Dec., 1 st week & Dec., 1 st week \\
\hline Seeding rate (kg/fed.) & 50 & 50 & 50 & 50 & 50 \\
\hline Row spacing (cm) & 20 & 20 & 20 & 20 & 20 \\
\hline N Level (kg/fed.) & 70 & 70 & 70 & 70 & 70 \\
\hline N Source & Urea & Urea & Urea & Urea & Urea \\
\hline Irrigation System & Surface & Surface & Surface & Sprinkler & Surface \\
\hline Number of Irrigations & 3 & 3 & 2 & 4 & 2 \\
\hline Harvesting date & Mid- May & Mid- May & Mid- May & Mid- May & Mid- May \\
\hline \multicolumn{6}{|c|}{$2014 / 2015$} \\
\hline Seeding date & Dec., 1 st week & Dec., 1 st week & Dec., 1 st week & Dec., 1 st week & Dec., 1 st week \\
\hline Seeding rate (kg/fed.) & 50 & 50 & 50 & 50 & 50 \\
\hline Row spacing (cm) & 20 & 20 & 20 & 20 & 20 \\
\hline N Level (kg/fed.) & 70 & 70 & 70 & 70 & 70 \\
\hline N Source & Urea & Urea & Urea & Urea & Urea \\
\hline Irrigation System & Surface & Surface & Surface & Sprinkler & Surface \\
\hline Number of Irrigations & 3 & 3 & 2 & 4 & 2 \\
\hline Harvesting date & Mid- May & Mid- May & Mid- May & Mid- May & Mid- May \\
\hline
\end{tabular}

Table (6): Pertinent mean squares (MS) due to various sources of variation of combined analysis across genotypes, seasons and locations.

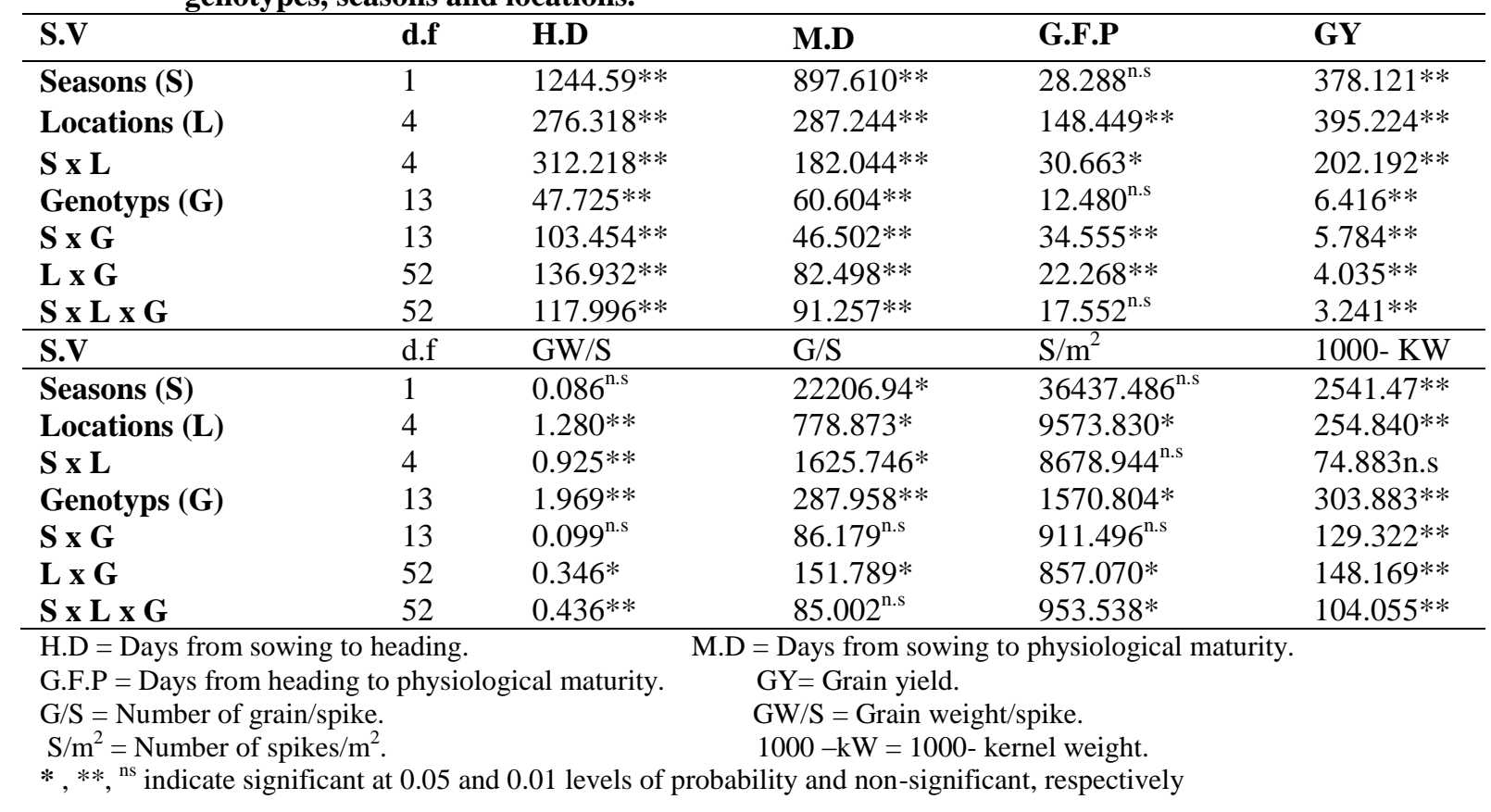

Table (7): Mean performance of studied characters in the 5 locations in combined across seasons (over genotypes, over seasons).

\begin{tabular}{|c|c|c|c|c|c|c|c|c|}
\hline & H.D & G.F.P & M.D & GY & GW/S & $\mathrm{S} / \mathrm{m}^{2}$ & $\mathbf{G} / \mathbf{S}$ & 1000- kW \\
\hline \multicolumn{9}{|c|}{ Combined across seasons } \\
\hline Nubaria & 93.0 & 34.51 & 127.51 & 5.25 & 2.62 & 419.40 & 53.25 & 45.97 \\
\hline Sahka & 92.0 & 33.51 & 125.51 & 6.04 & 2.65 & 405.40 & 53.57 & 47.50 \\
\hline Gimmeza & 90.0 & 34.01 & 124.01 & 5.93 & 2.69 & 405.54 & 54.50 & 49.22 \\
\hline Quntra Sharq & 85.0 & 28.04 & 113.04 & 3.32 & 1.99 & 365.40 & 45.89 & 47.58 \\
\hline Giza & 87.5 & 34.01 & 121.51 & 5.03 & 2.59 & 389.40 & 53.64 & 46.96 \\
\hline \multicolumn{4}{|c|}{$\begin{array}{l}\text { H.D = Days from sowing to heading. } \\
\text { G.F.P = Days from heading to physiological maturity } \\
\text { G/S = Number of grains/spike. } \\
\text { S } / \mathrm{m}^{2}=\text { Number of spikes } / \mathrm{m}^{2} .\end{array}$} & \multicolumn{5}{|c|}{$\begin{array}{l}\text { M.D = Days from sowing to physiological maturity. } \\
\text { GY= Grain yield. } \\
\text { GW/S = Grain weight/spike. } \\
1000-\mathrm{kW}=1000 \text { - kernel weight. }\end{array}$} \\
\hline
\end{tabular}


Table ( 8): Mean performance of 14 genotypes, combined across seasons and locations.

\begin{tabular}{|c|c|c|c|c|c|c|c|c|}
\hline Genotypes & H.D & G.F.P & M.D & GY & GW/S & $\mathrm{S} / \mathrm{m}^{2}$ & G/S & 1000- kW \\
\hline & & & \multicolumn{6}{|c|}{ Combined across seasons } \\
\hline L1 & 88.50 & 36.00 & 124.50 & 4.86 & 2.67 & 440.00 & 53.40 & 46.42 \\
\hline $\mathbf{L} 2$ & 83.60 & 33.70 & 117.30 & 5.96 & 3.13 & 465.60 & 63.10 & 53.53 \\
\hline $\mathbf{L 3}$ & 82.60 & 30.90 & 113.50 & 6.56 & 3.16 & 469.60 & 60.90 & 53.26 \\
\hline L4 & 90.00 & 34.60 & 124.60 & 4.84 & 2.52 & 364.00 & 49.10 & 47.42 \\
\hline L5 & 84.10 & 40.70 & 124.80 & 4.10 & 2.17 & 362.80 & 46.80 & 45.45 \\
\hline L6 & 99.00 & 25.40 & 124.40 & 3.96 & 1.93 & 362.80 & 45.00 & 44.11 \\
\hline L7 & 102.00 & 24.60 & 126.60 & 4.70 & 2.14 & 288.00 & 40.60 & 40.57 \\
\hline L8 & 100.00 & 22.30 & 122.30 & 5.06 & 2.20 & 370.00 & 47.40 & 45.47 \\
\hline L9 & 100.50 & 25.60 & 126.10 & 4.38 & 2.21 & 376.40 & 46.00 & 44.30 \\
\hline Giza 129 & 84.00 & 39.00 & 123.00 & 5.34 & 2.58 & 404.80 & 51.00 & 46.25 \\
\hline Giza 130 & 84.00 & 38.50 & 122.50 & 4.74 & 2.49 & 392.40 & 55.70 & 46.29 \\
\hline Giza 131 & 86.00 & 38.60 & 124.60 & 5.06 & 2.68 & 383.20 & 53.90 & 47.83 \\
\hline Giza 135 & 85.10 & 38.20 & 123.30 & 5.79 & 2.03 & 405.20 & 57.30 & 48.50 \\
\hline Giza 136 & 83.60 & 31.30 & 114.90 & 6.21 & 3.16 & 473.60 & 60.20 & 54.82 \\
\hline Means & 89.50 & 32.81 & 122.31 & 5.11 & 2.51 & 397.03 & 52.17 & 47.44 \\
\hline L.S.D & 5.05 & $\mathrm{~ns}$ & 9.69 & 0.83 & 2.68 & 7.42 & 4.69 & 2.31 \\
\hline \multicolumn{9}{|c|}{$\begin{array}{l}\text { H.D = Days from sowing to heading. } \\
\text { G.F.P = Days from heading to physio } \\
\text { G/S = Number of grain } / \text { spike. } \\
S / \mathrm{m}^{2}=\text { Number of spikes } / \mathrm{m}^{2} .\end{array}$} \\
\hline
\end{tabular}

Table (9): Simple correlation coefficient, simple linear regression equation and Coefficient of determination among phenological traits and yield and its component in across season.

\begin{tabular}{|c|c|c|c|c|}
\hline & \multicolumn{2}{|c|}{ Planting to flowering flowering to maturity } & Planting to maturity \\
\hline & & \multicolumn{2}{|c|}{ Simple correlation coefficien } & \\
\hline & $-0.567 *$ & 0.116 & $-0.849 * *$ \\
\hline \multicolumn{2}{|c|}{ Grain weight/spike } & $-0.635^{*}$ & 0.214 & $-0.810 * *$ \\
\hline \multicolumn{2}{|c|}{ Spikes $/ \mathrm{m}^{2}$} & $-0.691 * *$ & 0.264 & $-0.822 * *$ \\
\hline \multicolumn{2}{|c|}{ No. of grains/spike } & $-0.797 * *$ & 0.410 & $-0.804 * *$ \\
\hline \multicolumn{2}{|c|}{$1000 \mathrm{k} / \mathrm{w}$} & $-0.711 * *$ & 0.240 & $-0.901 * *$ \\
\hline \multirow[t]{2}{*}{ GY } & $\mathbf{R}^{2}$ & 0.3212 & 0.0135 & 0.7208 \\
\hline & liner regression & $=-0.0594 x+10.424$ & $=0.0151 \mathrm{x}+4.6148$ & $=-0.1614 x+24.855$ \\
\hline \multirow[t]{2}{*}{ Grain W/S } & $\mathbf{R}^{2}$ & 0.4026 & 0.0460 & 0.6556 \\
\hline & liner regression & $=-0.0359 x+5.7164$ & $=0.015 x+2.0091$ & $=-0.0831 \mathrm{x}+12.671$ \\
\hline \multirow[t]{2}{*}{ Spikes/m² } & $\mathbf{R}^{2}$ & 0.4768 & 0.0695 & 0.6760 \\
\hline & liner regression & $=-4.7879 x+825.55$ & $=2.2673 x+322.32$ & $=-10.349 x+1662.8$ \\
\hline \multirow[t]{2}{*}{ G/S } & $\mathbf{R}^{2}$ & 0.6352 & 0.1684 & 0.6463 \\
\hline & liner regression & $=-0.7222 x+116.81$ & $=0.4614 x+36.969$ & $=-1.3224 x+213.92$ \\
\hline \multirow[t]{2}{*}{$1000 \mathrm{k} / \mathrm{w}$} & $\mathbf{R}^{2}$ & 0.5059 & 0.0577 & 0.8125 \\
\hline & liner regression & $=-0.3816 x+81.594$ & $=0.1598 x+42.178$ & $=-0.8777 x+154.8$ \\
\hline
\end{tabular}

$\mathrm{GY}=$ Grain yield. $\quad \mathrm{G} / \mathrm{S}=$ Number of grain $/$ spike. $\quad \mathrm{GW} / \mathrm{S}=$ Grain weight $/$ spike. $\quad \mathrm{S} / \mathrm{m}^{2}=$ Number of spikes $/ \mathrm{m}^{2}$ $1000-\mathrm{kW}=1000$ - kernel weight. $\quad *, * *$, ns indicate significant at 0.05 and 0.01 levels of probability, respectively.

where it produced the highest grain yield. Its grain yield was reduced by 11.6, 23.1, 71.6 and $37.4 \%$ when it was grown at Sakha, Gimmeza, Quntra Sharq and Giza, respectively. Results also indicated that L8 genotype was more suitable to grow at Gimmeza location than other locations, where it produced the highest grain yield $(6.71 \mathrm{t} / \mathrm{ha})$ among other locations with valuable difference of 22.6, 8.5, 55.9 and $29.8 \%$ from its yield at Nubaria, Sakha, Quntra Sharq and Giza, respectively. Also, it was better to grow L4 at Nubaria location because it produced the highest grain yield among all the genotypes as well as its yield was reduced by 11.6, 23.1, 71.5 and $37.3 \%$ when it was grown at Nubaria, Sakha, Quntra Sharq and Giza, respectively. From these results it could be concluded that the superiority of L3, Giza 136 and L2 genotypes under the conditions of all locations may be due to their highest number of spikes $/ \mathrm{m}^{2}$ (data not presented). This was also true in the combined data across location and seasons (Table 8). This means that these genotypes are more tolerant than others to any stress conditions affect the culm mortality percentage and/ or spikes bearing culms $/ \mathrm{m}^{2}$. 
Table (10): Effect of locations $x$ genotypes interaction on grain yield $t /$ ha (combined across seasons).

\begin{tabular}{llllllll}
\hline Genotypes & Nubaria & Sakha & Gimmeza & Quntra Sharq & Giza & mean & L.S.D. 5\% \\
\hline L1 & 4.54 & 6.07 & 6.15 & 2.72 & 4.86 & 4.86 & 0.71 \\
L2 & 6.15 & 6.79 & 7.15 & 3.65 & 6.07 & 5.96 & 0.65 \\
L3 & 6.71 & 7.50 & 7.34 & 4.47 & 6.79 & 6.56 & 0.52 \\
L4 & 6.79 & 6.00 & 5.22 & 1.93 & 4.25 & 4.84 & 0.54 \\
L5 & 4.47 & 5.29 & 4.93 & 2.20 & 3.65 & 4.10 & 0.41 \\
L6 & 3.65 & 5.29 & 4.86 & 2.17 & 3.86 & 3.96 & 0.44 \\
L7 & 3.75 & 5.68 & 4.57 & 2.81 & 6.72 & 4.71 & 0.57 \\
L8 & 4.79 & 6.14 & 6.71 & 2.96 & 4.71 & 5.06 & 0.62 \\
L9 & 5.58 & 4.72 & 5.71 & 1.92 & 4.00 & 4.38 & 0.58 \\
Giza 129 & 5.96 & 6.15 & 5.71 & 4.25 & 4.64 & 5.34 & 0.31 \\
Giza 130 & 3.91 & 6.43 & 5.86 & 3.13 & 4.40 & 4.74 & 0.34 \\
Giza 131 & 5.00 & 5.50 & 6.00 & 4.27 & 4.54 & 5.06 & 0.39 \\
Giza 135 & 5.90 & 6.00 & 6.14 & 4.95 & 5.95 & 5.79 & 0.29 \\
Giza 136 & 6.25 & 6.93 & 6.72 & 5.07 & 6.07 & 6.21 & 0.27 \\
mean & 5.24 & 6.03 & 5.93 & 3.32 & 5.03 & 5.11 & ------- \\
L.S.D. 5\% & 0.31 & 0.35 & 0.27 & 0.48 & 0.29 & ------- & - \\
L.S.D. 5\% & (S x L G) & 0.83 & & & & & \\
\hline
\end{tabular}

From these results, it could be concluded that the most suitable genotypes for Nubaria location are L2, L3, L4 and Giza 136 while the most suitable ones for Sakha and Gimmeza locations are L2, L3 and Giza 136. However, Giza 136, Giza 135 and L3 are the most suitable genotypes for Quntra Sharq location. Meanwhile, L2, L3, L7 and Giza 136 genotypes were superior at Giza location. This means that L3 genotype and Giza 136 cultivar had stable productivity under the conditions of these locations. Also L3 genotype is a promising line to release as a good variety in general and under high productive environments in particular. However, Giza 136 was stable and also adapted to less productive environments. Abdel-Raouf et. al. (2016) reported this conclusion through stability and adaptation parameters. Similar results were found by Al-Otayk (2010), ElAmeen (2012) and Mohamed et al. (2013) and Lodhi et al. (2015).

\section{REFERENCES}

Abad A., Khajehpour M. R., Mahloji M. and Soleymani A. (2013). Evaluation of phenological, morphological and physiological traits in different lines of barley in Esfahan region. Int. J. Farm \& Ali Sci., 2(18): 670-674.

Abdel-Raouf M.S., A.A. Kandil A.A. El-Sayed and A.M. Attya (2016). Performance and stability of hull-less barley genotypes grown at different environments in Egypt. Under publication.

Al-Otayk S.M. (2010). Performance of yield and stability of wheat genotypes under high stress environments of the Central Region of Saudi Arabia. Met. Env. Arid Land Agric. Sci., 21: 81-92.

Al-Tabbal J. A. and Al-Fraihat A. H. (2012). Genetic variation, heritability, phenotypic and genotypic correlation studies for yield and yield components in promising barley genotypes. J..Agric. Sci., 4(3):193-210.

Ataei M. (2006). Path analysis of barley (Hordeum vulgare L.) yield. Tarim Bilimleri Dergisi, 12(3): 227-232.

Dofing S. M. (1995). Phenological development-yield relationships in spring barley in a subarctic environment. Can. J. Plant Sci. J.,( 751): 93-97.

El-Ameen T. (2012). Stability analysis of selected wheat genotypes under different environment conditions in upper Egypt. Afr. J. Agric. Res.(7): 4838-4844.

Gomez A. K. and Gomez A. A. (1984). Statistical Procedures for Agricultural Research. John Wiley and Sons (pub). New York, USA.

Hossain A., Teixeira da Silva J. A., Lozovskaya M. V., Zvolinsky V. P. and Mukhortov V. I.(2012). High temperature combined with drought affect rainfed spring wheat and barley in south-eastern Russia: Yield, relative performance and heat susceptibility index. J. Plant Breed. and Crop Sci. 4(11): 184-196. 
Kalra N., Chakraborty D., Sharma A., Rai H.K., Jolly M., Chander S., Kumar P.R., Bhadraray S., Barman D., Mittal R.B., Lal M. and Sehgal M. (2008). Effect of increasing temperature on yield of some winter crops in northwest India. Current Sci., (94): 1-10.

Lodhi R.D., L.C. Prasad, S.S. Bornare, A.H. Madakemohekar and R. Prasad (2015). Stability analysis of yield and its component traits of barley (Hordeum vulgare L.) genotypes in MultiEnvironment trials in the North Eastern plains of India. Sabro J. Breed. and Genet. 47(2): 143-159.

Mohamed S. H., G.I.A. Mohamed and R. A. R. El-Said (2013). Stability analysis for grain yield and its components of some durum wheat genotypes (Triticum durum) under different environments. Asian J. of Crop Sci. 5(2): 179-189.

Mondal S., Singh, R.P., Mason, E.R., HuertaEspino, J., Autrique, E. and Joshi, A.K. (2016). Grain yield, adaptation and progress in breeding for early-maturing and heat-tolerant wheat lines in South Asia. Field Crops Res. 192): 78-85.

Montazeaud G., Karatoğma H., Özturk I., Roumet P., Ecarnot M., Crossa J., Özer E., Özdemir F. and Lopes M. S. (2016). Predicting wheat maturity and stay-green parameters by modeling spectral reflectance measurements and their contribution to grain yield under rainfed conditions. Field Crops Res. 10: 1016- 1023.

Nwaosu S. C. and Onuche P. (2014).
Determination of maturity date barley crops using lognormal parametric survival function. Adv. Appl. Sci. Res., 5(2): 220228.

Okuyama L. A., Federizzi L. C. and Neto J. F. B (2004). Correlation and path analysis of yield and its components and plant traits in wheat. Ciência Rural, Santa Maria (34): 1701- 1708.

Reinhardt D. Jansen G. Seddig S. and EichlerLobermann B. (2013). Temperature stress during flowering time affects yield and quality parameters of waxy barley. Appl. Agric. Forestry Res., 1(63):79-84.

Talukder A.S.M.H.M., McDonald, G. K. and Gill, G.S. (2014). Effect of short-term heat stress prior to flowering and early grain set on the grain yield of wheat. Field Crops Res. 160: 54-63.

Tao F., Zhang Z., Xiao D., Zhang S., Rötter R. P., Shi W., Liu Y., Wang M., Liu F. and Zhang H.(2014). Responses of wheat growth and yield to climate change in different climate zones of China, 19812009. Agric. and Forest Meteoro.,189-190: 91-104.

Tsenov N. (2009). Relation between time to heading and date of maturity of winter common wheat varieties (Triticum aestivum L.). Agr. Sci. and Tec., 1(4): 126 - 132.

Yau S. K. and Ryan J. (2013). Differential impacts of climate variability on yields of rainfed barley and legumes in semi-arid Mediterranean conditions. Arch. of Agron. and Soil Sci. 1(10): 1080- 1096. 


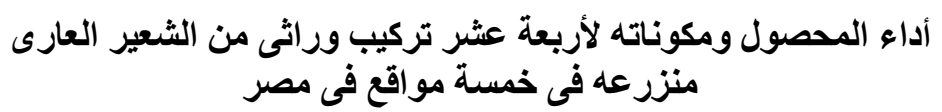

محمد صبرى عبد الروؤف ـ عبد العزيز قنديل أحمد ـ *عبد الفتاح احمد السيد ـ *|حمد ماهر عطيه

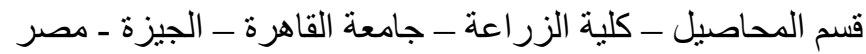

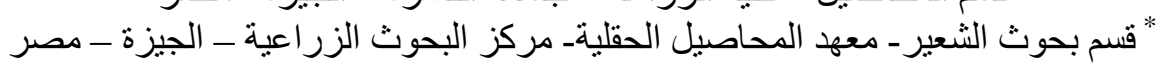

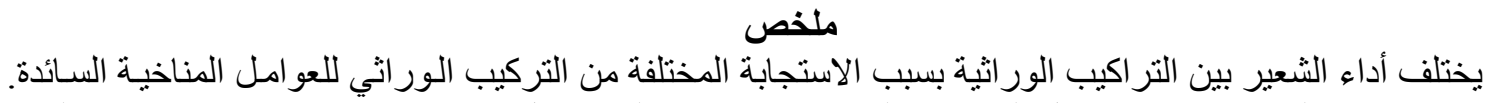

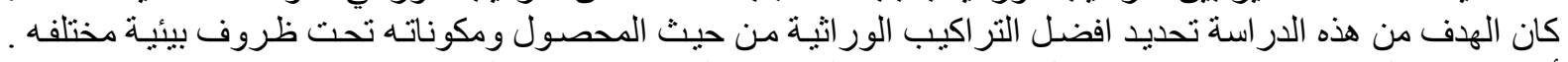

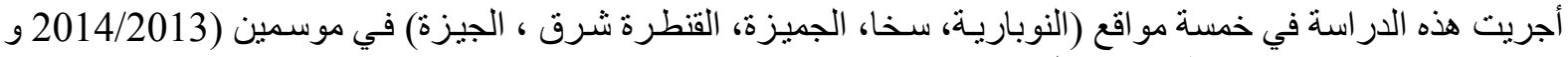

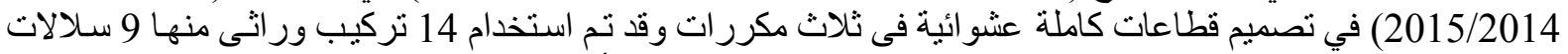

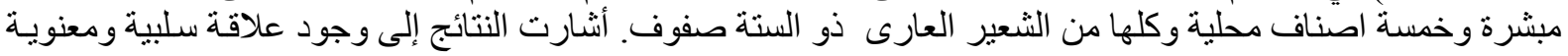

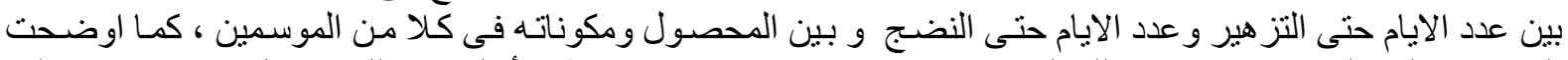

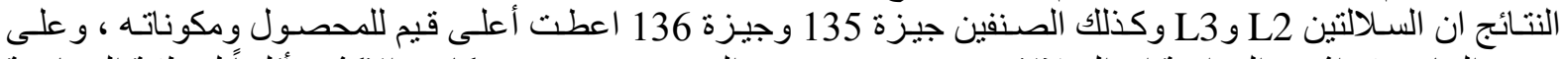

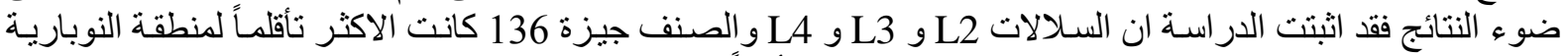

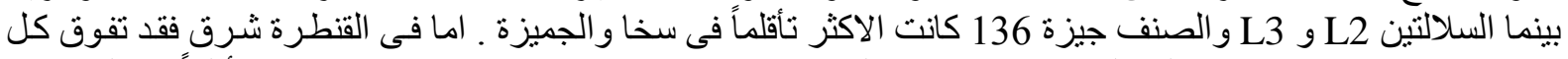

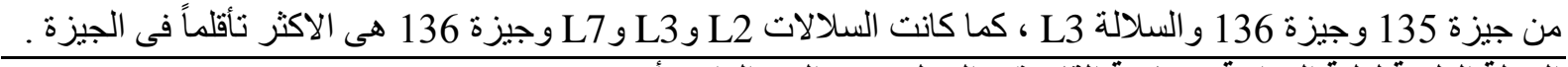

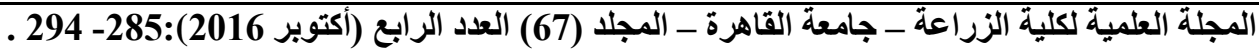

